\title{
総説
}

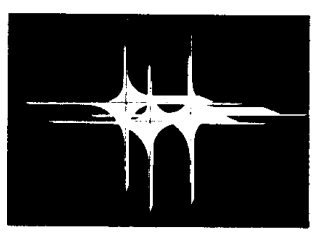

\section{ディスポーザブル製品の現状と将来 新しい製品の開発と関連して}

\section{厅 川達男*}

医燎用ディスポーザブル製品の種類は，現在 でも非常に多く，可能性も考え机ば極めて広範 团にわたるがこここではとくに生体計測のディ スポーザブル製品に限って，現状上将来の问能 性の検討を試みる。

\section{1. 生体計測のためのディスポーザブル 製品の特徵}

従来のディスポーザブル製品は, 容器, チュ 一ブ，針などのような，比較的単純な器具類が 多く、ディスポーザブルにすることの放らいは， 材料の污染, 劣化に上る危険を避け, 洗浄, 保 管などの手数を省くことであったように思わ机 る.これに対して生体計测用の機器をディスポ ーザブルとすることには，则な目的がある上考 えられる。

すなわち, 生体計測機器に注生体から情報を 抽出するトランスデューサが必要であるが，精 密なトランスデューサが精密にな礼ばなるほど， くり返し使用しても姿全で信頼性の高いものを 製作することが困難となる。そこで，小型で信 頼性が高く，安全なトランスデュー步目標上 する場合, ディスポーザブル製品とすることが 1つの解決法である。またディスポーザブルと 寸ることで，不可逆変化を利用することなども 考えら的，トランスデューサとして利用できる 手段も抬大さ机る。このようなことから，生体 計測用のディスポーザブル製品としては，高度 に機能的なものの可能性が考えられる。

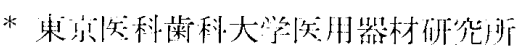

以下に生体計測用の機能的なディスポーザブ ル機器として, 現在すでに使用されているもの, および将来ディスポーザブルとすることが有望 上考えられるものについて検討寸る。

\section{2. 体内に挿入される機器および器具}

生体内情報の直接計測のため, 計測機器ある いはその一部を体内に挿入寸る必要が生ずる。 トランスデューザが大型で体内に挿入できない 場合，管などで体内訪測部位と連結寸る方法， たとえば体内王を液を満たしたカテーテルで体 外に置か机た压力部に導くような方法がある。 また小型のトランスデューサ，たとえばカテ先 圧力トランスデューサなどを值接に計測部位に 挧入寸ることにより，外界や導管の影響なく体 内情報が計測できる。さらにテレメータにより， 皮膚に管やリード線を貫通させずに，体内から 情報を得ることも可能である（眓 1 ）。
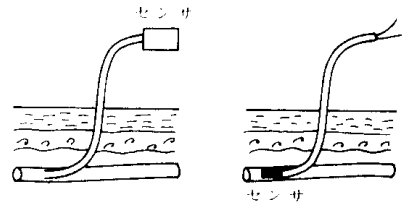

t?

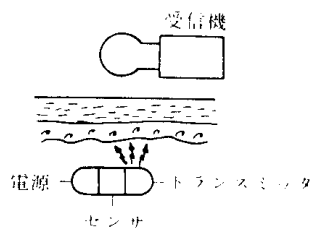

i.i
図 1 体内情報の直接計測の方法

この上うに体内に扫入, 留置あるいは植込み 使用される計測機器, 器具は, ディスポーザブ ルとすることが望ましいものである。

カテ先压力トランスデューサはまだ完全にデ イスポーザブルとなってはいないが，極小面積 の受压板によって高感度を得るために構造的に 
は丈夫に作ることが困難であり，洗浄，消毒を くり返しても高い信頼性を保証できるものを開 発するよりむしろ, ディスポーザブルとして安 全性，信頼性を保証し，製造技術の開発によっ て価格の低減化を計った方が有利である可能性 が考えられる.

熱希䣋法による血流計測用の Swan-Ganz カ テーテルは，すでにディスポーザブルとなって おり，機能的ディスポーザブル製品の将来の方 向を示すものとして, 注目すべきものである。

血液ガスモニタ一も体内直接計測が要望され ているものであり，ポーラログラフ方式の酸素 電極には，すでにディスポーザブルの製品があ る.ポーラログラフ電極は, 電流によってわず かながら電解質を消費するので, 極小型電極で は寿命が短くなり，更使用するに注電解質の補 充のため膜の交換が必要となり，扱いに熟練を 要するが，ディスポーザブルであれば扱いが容 易になる. 同様に各種イオン電極, グルコース 電極なども，実用化される段階ではディスポー ザブル化が考慮されるものと考えられる，

消化管内計測のための消化管カプセル，すな わち消化管内の温度, 压力, $\mathrm{pH}$ などを計測し て，テレメータによって体外に情報を送るもの が，すでに臨床に使用されているが，現在は高 価であり，ディスポーザブルとなっていないが， 使用後の回収に手数と時間を要し, また小型で あるため, 電池交換など, 更使用のための配虑 により構造が複雑化している。したがって, 広 く臨床使用されるには，ディスポーザブル化が 望ましいと考えられる。

\section{3. 体表に装着される機器および器具}

体内の物理量, 化学量情報を体表から無侵襲 的に計測する方法が種々ある（図2），それに

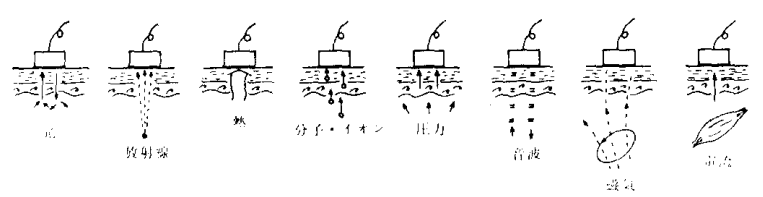

図 2 皮膚を介して計測される量

は, 多くの場合, 体表に計測機器あるいは器具 を装着する必要がある。安全性については, 体 内に雨入するものほど㛜しいことは要求されな
い代わりに，使用対象，使用条件の範用が広く， 不快感を与えず，みた目にも好ましいものが要 求される。十なわち, 安全性, 信頼性のほかに, 感覚的, 心理的配慮が必要であり, それらの条 件を満たすにはディスポーザブルとすることが 有利であることが多いと思われる。

たとえば心電図等の導出電極は, すでに多く のディスポーザブル製品が用いられており, 清 潔で見た目にも良く，使用後の洗浄などの手数 がかからず，さらに性能的にみても，金属の腐 蝕, 污れによる雑音や接触不良の問題がなく, また電解質 (ペースト) が充填されていもので は, 電極表面が電気的汇安定した状態で使用開 始できる点でも好ましい，体表電極は, 導出電 極のほか, 刺激電極, インピーダンス法のため の通電および検出電極, 電気入ス対極板などい ずれもディスポーザブル製品が開発されている.

体温計も一種の体表装着計測器であるが, 電 子体温計のサーミス夕部分, とくに口修温計の 場合, 1 人の患者に 1 本を使用し, 他の患者に 使用しないようにしているものがあり, 清潔で, 心理的にも好ましい. またディスポーザブル体 温計として開発されたケミカルインジケータは， 一定温度で膜が融けて色素を含む液体が抁散し て発色するものであり，不可逆的であることか ら，原理的にディスポーザブルを前提としてい る.

このほか光電脈波形, 放射線検出器, イオン, ガスセンサ，圧力センサ，超音波素子など，体 表に装着する計測機器が種々あり, 将来ディス ポーザブルとすることが有効なものも少なくな いと思わ机る。

\section{4. 呼吸計測用機器および器具}

呼吸器系に用いる器具は, 気道感染に対する 配慮から，消毒して用いられることが望ましい が, 呼吸計測用機器の消毒は必ずしも容易でな く, マウスピースなど直接触れる部分だけ消毒 された器具を使用する程度で済まされる場合 も多い、しかしすでにディスポーザブル気流速 計（Spirostat@）が開発された例があり，また ディスポーザブルの呼吸用熱湿交換器 (Heat moisture exchanger) を用いてニューモタコグ 
ラフの原理で呼吸モニターを行ら方法も試みら れた。このようなことから呼吸計測用のディス ポーザブル機器も将来の可能性が大きいと思わ れる。

\section{5. まとめ}

以上のように生体計測用の機器においては, 将来, トランスデューサのディスポーザブル化 の可能性が考えられ，とくに，体内に扥入した り体表に装着するもの，あるいは呼吸計測用の ものが考えら机る。こ机らのうちの多くのもの は，高度に機能的なディスポーザブル製品とな
ると考えられる。トランスデューサのような機 能的な器材をディスポーザブル化することの利 点として，安全で扱いを容易にすることのほか に，くり返し使用寸ることによる性能の劣化が 避けられ, 計測精度, 信賴性の向上が期待でき ることに注目寸べきであると考えられる。

注）本論文注昭和56年 5 月28日東東で開催された第 56可日本医科器械学会大会シンポジウムI「デ イスポーザブル製品の現状上将来」に扔ける講 演要旨である。(編集部)

(編集部) 